\title{
LOCAL EARTHQUAKE TOMOGRAPHY IN THE BROADER AREA OF WESTERN CORINTH GULF
}

\section{Karakonstantis A. ${ }^{1}$ and Papadimitriou P. ${ }^{1}$}

${ }^{1}$ National and Kapodistrian University of Athens, Department of Geology-Geoenvironment, Labor atory of Seismology, Ilisia, Zografou, 15784 - Greece, akarakon@geol.uoa.gr, ppapadim@geol.u oa.gr

\begin{abstract}
In this study, we applied Local Earthquake Tomography in order to investigate the detailed 3-D structure within and around the broader region of Western Corinth Gulf which is one of the most seismically active regions in the world. We use data from the 2012-2014 time-period, selecting about 2,000 seismic events recorded by the local seismic stations of Hellenic Unified Seismological Network (HUSN) and the Corinth Rift Laboratory Network (CRLN). Applying Tomographic Inversion, we produce and interpret 3-D models of $V p, V s$ and $V p / V s$ ratio in the study area. The obtained results shows several distinct structures, namely areas of high and low $V p / V s$ ratio correlating the hypocenter distribution with changes in lithology or fluid concentration. In the area of Patraikos Gulf, an ascending velocity volume was traced that could possibly be connected to salt tectonics in the alpine basement, effecting the fluid circulation as well as the behavior of local faults.
\end{abstract}

Keywords: Local earthquake Tomography, velocity models, Salt tectonics, Greece.

\section{Пврі́ $\eta \psi \eta$}

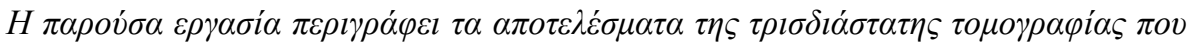

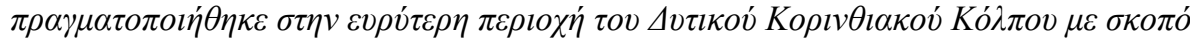

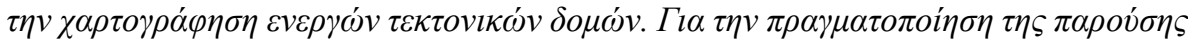

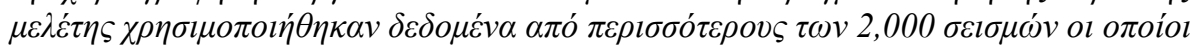

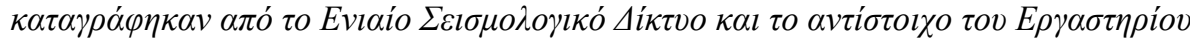

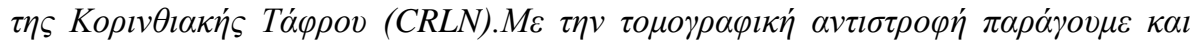

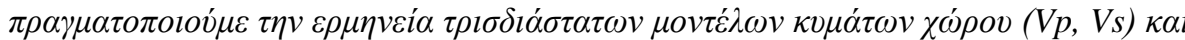

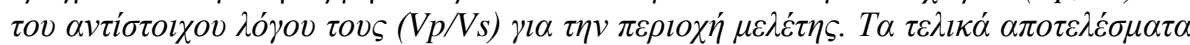

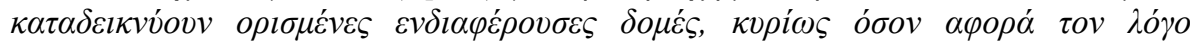

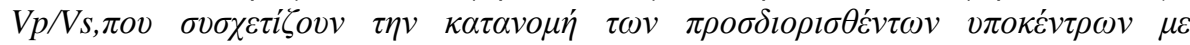

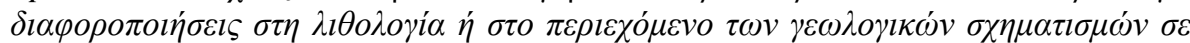


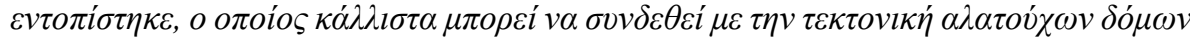

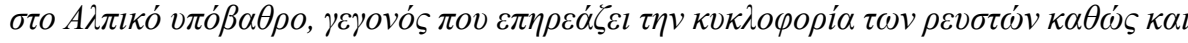

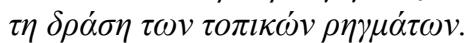

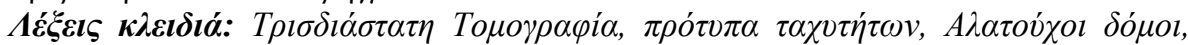
$E \lambda \lambda \alpha \dot{\alpha} \delta$. 


\section{Introduction}

Greece is located to the eastern end of Europe where a variety of geological procedures take place such as the Alpine orogenesis. The creation of the Alpine mountain chain, which is one of the most important geological features, is caused by the collision between Europe and Africa. Furthermore, an intense deformation observed in Greece and surrounding areas produces important seismicity concentrated in certain seismic zones, such as the Hellenic Arc, characterized by subduction, the North Aegean, dominated by dextral strike-slip faulting, and the back arc area dominated by normal faults.

The Gulf of Corinth has been identified as one of the faster expanding (1 to $1.5 \mathrm{~cm} /$ year of northsouth extension) and most seismically active continental rifts around the world, characterized by normal faulting in an approximate E-W direction (Rigo et al., 1996; Makropoulos and Burton, 1981; Papazachos and Papazachou, 1997).The most active normal faults of the Gulf are dipping north, resulting a long term subsidence of the northern coast and an upward displacement of the main footwalls, giving the impression of an asymmetrical rift structure (Armijo et al., 1996). The area under study is dominated by Alpine Carbonate formations of the H1 (External Hellenides Platform) and H2 (Cyclades-Pindus ocean crust) terrains, and Plio-quaternary sediments in the northern shores of Peloponnese. The subsiding Hellenides limestone nappes to the north of the gulf are outcropping in the majority of sites, whereas to the south, these formations are mostly covered by a conglomerate layer of several hundreds of meters thickness that outcrops only on the footwall of the southern active faults (Armijo et al., 1996; Pitilakis et al., 2004; Cornet et al., 2004).

In the framework of this study, a tomographic inversion of the local recorded seismicity was performed obtaining a reliable 3-D body-wave velocity model with the respective $\mathrm{Vp} / \mathrm{Vs}$ ratio in order to trace main active geologic features through the resulting discontinuities.

\section{Data and analysis}

\subsection{Data sources}

The present study focuses in the area of Western Corinth Gulf, where data obtained by local stations of the Hellenic Unified Seismological Network (HUSN) and Corinth Rift Laboratory (CRL) were used for the construction of regional and local 1D and 3D velocity model, concerning the 2012-2014 time period.

HUSN comprises twenty-eight (28) seismological stations from the Seismological Laboratory of the University of Athens (S.L-U.O.A), fifty (50) of the Geodynamics Institute of the National Observatory of Athens (GE.IN.-N.O.A), forty (40) of the Geophysical Laboratory of the University of Thessaloniki (G.L.-A.U.TH) and twenty-four (24) of the Seismological Laboratory of the University of Patras (U.P.S.L.). Since 2007, continuous waveform recordings are being obtained from HUSN in real-time, comprising of both 1-component $(1 \mathrm{~Hz})$ and 3-component (either broadband or short-period) stations, while manual arrival-time picking is being applied to obtain more accurate hypocentral locations.

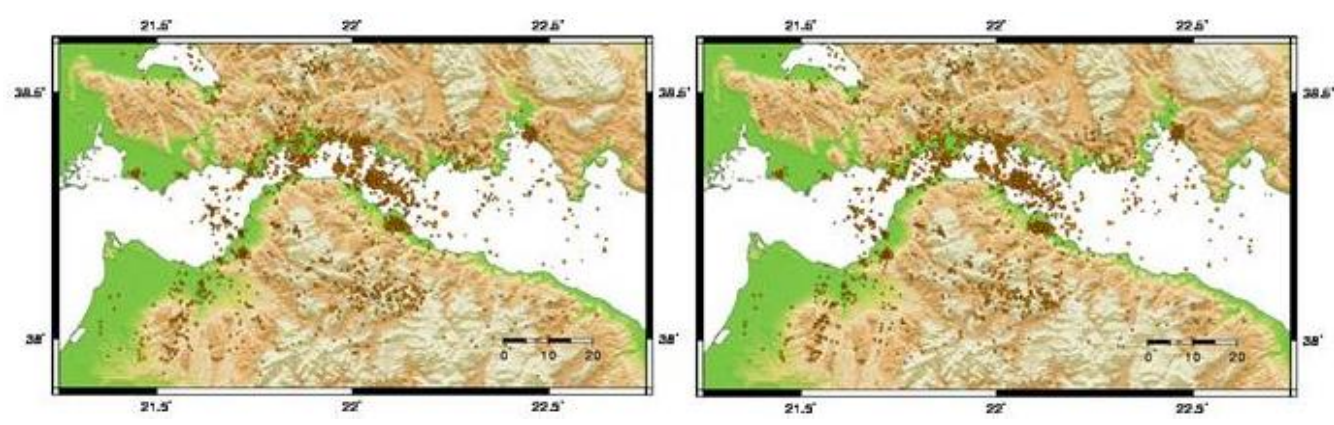

Figure 1 - Located seismicity $(M \geq 1.4)$ using regional 1-D velocity model (left) of Kaviris (2003) and the obtained local 1-D velocity model by the current study (right). 
On the other hand, the Corinth Rift Laboratory Network (CRLN) is made up of twelve stations installed in the broader area of Western Corinth gulf, seven on the southern shores and five on the northern coast. Since its installation in mid-2000, the CRLN has recorded many tens of thousands of earthquakes in the Western Corinth Rift, with magnitudes as low as $\mathrm{M} \approx 1$ (Lyon-Caen et al., 2004).

A preliminary hypocenter location has been performed for the seismicity of the broader area and the 2012-2014 time period, using the HYPOINVERSE code (Klein, 1989) and an initial regional 1D velocity model derived by (Kaviris, 2003). Upon selection, the resulting data set was composed of 2,123 earthquakes. By employing a subset of events located with accuracy better than $4 \mathrm{~km}$ and having RMS $<0.2 \mathrm{~s}$, the average $\mathrm{Vp} / \mathrm{Vs}$ ratio and the $1 \mathrm{D}$ velocity structure of the area were investigated, using the mean travel-time residuals and location uncertainties (RMS, ERH, ERZ) minimization method (Kissling et al., 1994; Chiarabba and Frepoli, 1997). A 1D velocity model was obtained (Table 1), yielding improved hypocenter solutions for the whole dataset (Figure 1). The calculated median hypocentral location uncertainties, obtained by HYPOINVERSE using the optimum local velocity structure, are ERH $=0.34 \mathrm{~km}, \mathrm{ERZ}=0.73 \mathrm{~km}$, and $\mathrm{RMS}=0.14 \mathrm{~s}$, while the corresponding median error values using the regional model are $\mathrm{ERH}=0.38 \mathrm{~km}, \mathrm{ERZ}=0.88 \mathrm{~km}$ and $\mathrm{RMS}=0.17 \mathrm{~s}$, respectively.

\subsection{Tomographic Algorithm}

Seismic tomography is proven an effective tool for the detailed investigation of the Earth's interior. The scope of the present tomography study is to determine the crustal structure in the broader area of Western Corinth Gulf, in order to identify the local activated faults through velocity variations using manually located events. Local earthquake tomography techniques have successfully been applied to reveal the velocity structure of active tectonically regions (Drakatos et al., 2002; Koulakov et al., 2010). In the present study, the analysis was based on the local tomographic inversion code (LOTOS) by Koulakov (2009). For the tomographic inversion, more than 2,000 manually located events were taken into account, as a primary catalogue. Synthetic testing (checkerboard) was performed to set the parameter's values that produce better resolution and increase the area of fidelity. For the 3-D tomography inversion, a dataset comprising of $51231 \mathrm{P}$ and $37267 \mathrm{~S}$ arrival-times, was selected, with at least 12 phases and ratio of $\mathrm{S}$ to $\mathrm{P}$ residual smaller than 1.5. Inversion was performed for $\mathrm{Vp}, \mathrm{Vs}$ and $\mathrm{Vp}-\mathrm{Vp} / \mathrm{Vs}$ to obtain additional constraints concerning the Vp and Vs anomalies. The LOTOS code requires input data of the station coordinates and the arrival times from locally recorded seismicity. The coordinates of the hypocenter and the origin time are not essential, as they are determined during the execution of calculations. However, if preliminary hypocentral locations are available, as in the present case, they are used to decrease the processing time of the operations. Additionally, the obtained 1-D starting velocity model and a set of input parameters for performing the convergence iteration steps, including parameterization, grid dimensions and damping parameter, were considered (Koulakov, 2009). Model parameterization of the velocity field delineates, according to the local characteristics, the shape and position of heterogeneities. A nodal representation was employed, keeping the spacing between the nodes of the grid considerably smaller than the expected size of the anomalies $(<8 \mathrm{~km})$ in order to reduce the bias of the resulting models due to the grid configuration. The optimal grid mesh has been determined taking into account the stations/events geometry. In addition, to further decrease the influence of the model parameterization on the solutions, the inversion was repeated using several grid orientations $\left(0^{\circ}, 22^{\circ}, 45^{\circ}\right.$ and $\left.67^{\circ}\right)$. The obtained results were combined over a 3-D model of absolute $\mathrm{P}$ and $\mathrm{S}$ velocities by simple averaging. 
Table 1 - Comparison between the local velocity model by Kaviris (2003) and the custom velocity model calculated for this study.

\begin{tabular}{|c|c|c|c|c|}
\hline & \multicolumn{2}{|c|}{$\begin{array}{c}\text { Kaviris., 2003 } \\
\text { (KM) }\end{array}$} & \multicolumn{2}{c|}{$\begin{array}{c}\text { This study } \\
\text { (CM) }\end{array}$} \\
\hline $\mathbf{V}_{\mathrm{p}} / \mathbf{V}_{\mathbf{s}}$ ratio & \multicolumn{2}{|c|}{1.79} & \multicolumn{2}{c|}{1.78} \\
\hline Layer & $\begin{array}{c}\text { P-wave Velocity } \\
(\mathrm{km} / \mathrm{s})\end{array}$ & $\begin{array}{c}\text { Ceiling } \\
\text { Depth }(\mathrm{km})\end{array}$ & $\begin{array}{c}\text { P-wave Velocity } \\
(\mathrm{km} / \mathrm{s})\end{array}$ & $\begin{array}{c}\text { Ceiling } \\
\text { Depth }(\mathrm{km})\end{array}$ \\
\hline 1 & 4.8 & 0.0 & 5.1 & 0.0 \\
\hline 2 & 5.2 & 4.0 & 5.4 & 3.0 \\
\hline 3 & 5.9 & 9.0 & 5.8 & 7.0 \\
\hline 4 & 6.1 & 11.0 & 6.1 & 11.0 \\
\hline 5 & 6.3 & 16.5 & 6.4 & 20.0 \\
\hline 6 & 7.4 & 35.0 & 6.8 & 29.0 \\
\hline 7 & 8.1 & 80.0 & 7.4 & 40.0 \\
\hline 8 & - & - & 8.0 & 55.0 \\
\hline
\end{tabular}

\section{Results}

\subsection{Checkerboard tests}

In the present study the checkerboard method (Humphreys and Clayton, 1988) was performed as indicator of the resolution and errors associated with the inversion in order to define the fidelity area. This kind of test uses alternating anomalies of high and low velocity evenly spaced throughout the model in a three-dimensional checkerboard pattern. Data resolution is mainly controlled by ray-path distribution, model parameterization, and smoothing.

Checkerboard tests are performed in order to reproduce the procedure of real data processing. In the initial checkerboard model the size of cells corresponds to the expected anomalies that can be found in similar studies. The checkerboard procedure used, involves defining many spiked regions with $\pm 15 \%$ in the variability of Western Corinth Gulf velocity structure compared to the one-dimensional reference model. Random noise of $0.15 \mathrm{~s}$ for $\mathrm{P}$ picks and $0.25 \mathrm{~s}$ for $\mathrm{S}$ picks was added to the residuals, following a normal distribution, in order to approximate the uncertainties of the $3 \mathrm{D}$ model, using the same parameterization as for the real data as it is described by Koulakov (2009). Then the travel-times for the paths between source and receiver were computed. This procedure corresponds to the real observation system which uses a 3-D ray tracing that follows the bending algorithm principles.

After the computation of the synthetic travel-times, information of coordinates, origin time of sources and velocity model is no longer available. The reconstruction of the synthetic model is performed in the same way as in the real data processing, including the optimization of the 1-D model and the absolute source location. The same values of free parameters, as in the real case, are used in order to examine the area of fidelity for our results. The inversion variance is controlled by errors in the data including mis-picks, mis-locations, and incorrectly determined ray-paths. Several checkerboard tests were performed in order to obtain the most representative cell size for the horizontal resolution of each case. The size of the cell that in which the synthetic model is resolved corresponds to $5 \mathrm{~km}$. 

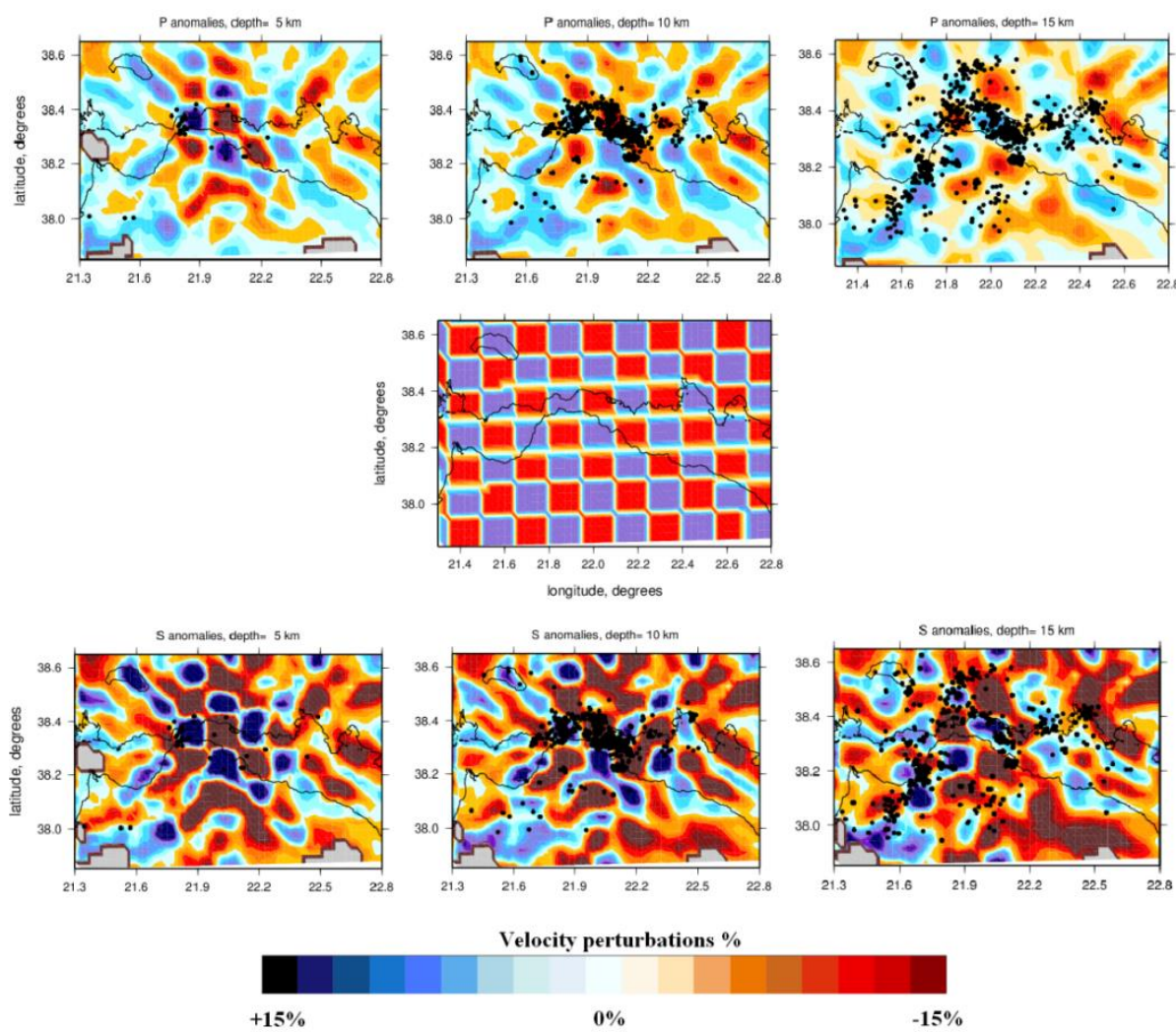

Figure 2 - Starting checkerboard anomaly distribution (central panel) and the resulting P(upper panel) and S-velocity (lower panel) anomalies for the depth slices of 5, 10 and $15 \mathrm{~km}$. The black dots indicate local earthquakes in the corresponding depth levels.

As it can be seen in the figure 2, the fidelity area can be judged as satisfactory since the initial model was reconstructed successfully in both $\mathrm{P}$ and $\mathrm{S}$ waves in the study area. More specifically, the size and shape of the anomalies were fairly preserved in the central part of the broader area of Western Corinth Gulf, while the synthetic results were gradually deteriorating towards the edges of the study area, for depth slice of $15 \mathrm{~km}$. due to poor ray coverage. This fact provides reliability to the interpretation of the final results for body-wave perturbations as well as $\mathrm{Vp} / \mathrm{Vs}$ ratio tomograms in the section below.

\subsection{Real-Data Inversion}

The earthquake data used in the current study comprise more than 2,000 seismic events recorded by HUSN and CRLN in the area of Western Corinth Gulf. The main purpose of this study is to detect certain regional and local activated tectonic features through resulting velocity anomalies in the resolved areas.

Regarding the 1D inversion, the observed data processing starts with preliminary source locations and optimization of the velocity model. In figure 3, it can be seen the final result obtained by the optimization procedure. The resulting 1D Vp and Vs profiles, for both regional and local models, seem to converge to a similar behaviour for the depth interval $10-35 \mathrm{~km}$.

The resulting body-wave anomalies and $\mathrm{Vp} / \mathrm{Vs}$ ratio obtained by the $3 \mathrm{D}$ tomographic inversion are presented for the depth slices of 5,10 and $15 \mathrm{~km}$ (Figure 4). The mean computed $\mathrm{P}$ and $\mathrm{S}$ anomalies for the study area do not exceed the absolute values $12 \%$ and $14 \%$ respectively. 


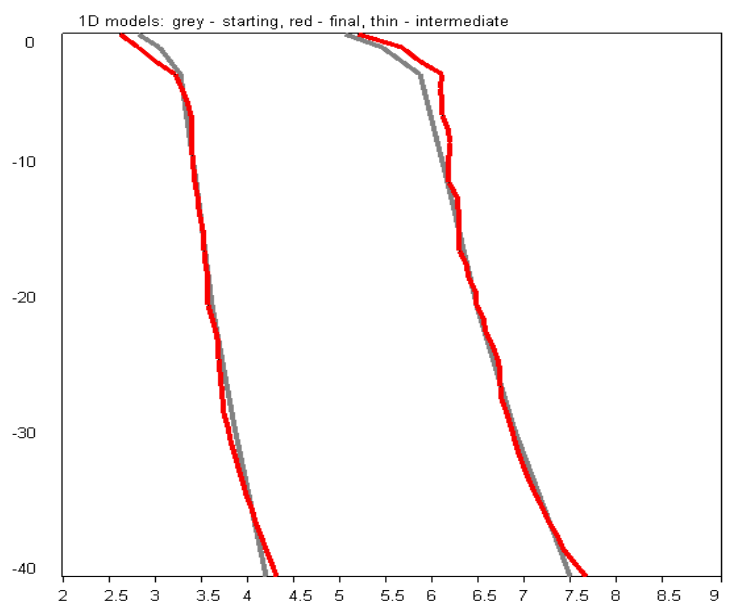

Figure 3 - Optimization results of the 1D velocity model (red line) setting as starting model the one obtained by the current study (grey line).

The orientation of $\mathrm{P}$ and $\mathrm{S}$ wave anomalies is affected by both active faults such as Andravida Fault Zone (AFZ), Kato Achaia normal fault (KANF) and local surface geology (Koulakov et al., 2010). Some interesting features of this study are revealed through anticorrelation of higher $\mathrm{P}$ and lower $\mathrm{S}$ velocities and as a consequence high $\mathrm{Vp} / \mathrm{Vs}$ ratio values (1.90-2.06) parallel to the mean direction of mapped faults and thrusts in which are mainly connected to tectonic grabens filled with a thick layer of recent sedimentary deposits or fracturation and fluid penetration along the fault plane such as the case of AFZ. The presence of high Vp/Vs ratio values at $15 \mathrm{~km}$ depth in AFZ case indicates that the rupture area consists of relatively small aspect ratio water-filled pores of the basement rock under overpressured conditions, as similar cases has shown (Takei, 2002; Nakajima et al., 2006). On the other hand, the unfractured parts of the crust are clearly expressed as high-velocity and low $\mathrm{Vp} / \mathrm{Vs}$ ratio structures such as Antirrion and Nafpaktos basins in the northern coasts of Patraikos and Western Corinth Gulf respectively. In other parts of the study volume a fairly good qualitative correlation of $\mathrm{P}$ and $\mathrm{S}$ anomalies is observed. Strong lateral velocity perturbations are mainly recognized at superficial depths $(0-15 \mathrm{~km})$, while below $30 \mathrm{~km}$ the overall image changes. More specifically, in the depth slice of $5 \mathrm{~km}$ depth, SW of Patras, a NNW-SSE oriented discontinuity of positive to the south and negative to the north body-wave velocity anomalies is seen, coinciding with KANF, dividing the Alpine basement of Gavrovo geotectonic and quaternary deposits respectively. Moreover, a similar striking feature is observed to the east, near Aigion, can be linked to Aigion normal fault which is in accordance with recent tomographic and seismotectonic studies (e.g. Gautier et al., 2006). More specifically, as in the case of AFZ, a high Vp/Vs ratio zone trending in WNW-ESE direction, parallel to the Corinth Rift, is situated offshore to Helike between the depth slices of $5-15 \mathrm{~km}$ below sea level (b.s.l). This feature is associated to a highly fractured zones facilitating the circulation of deep fluids, reducing the friction coefficient and allowing seismic slip along the low-angle detachment as it is mentioned in previous studies (Rietbrock et al., 1996; Gautier et al., 2006).

The cross-sections (Figure 5) performed parallel $\left(\mathrm{N} 120^{\circ} \mathrm{E}\right)$ and quasi-perpendicular $\left(\mathrm{N} 40^{\circ} \mathrm{E}\right)$ to the Western Corinth Gulf reveal a superficial layer with absolute values of P-velocity between 5.5-6.4 $\mathrm{km} / \mathrm{sec}$ which is laterally succeeded by a high velocity layer bilaterally (Vp 6.7-7.2 km/sec). More specifically, in the profile 1A-1B (Figure 5), a diapir with P-velocity absolute values of 6.2-6.4 $\mathrm{km} / \mathrm{sec}$ reaches the uppermost level of the crust $(<2 \mathrm{~km}) 25 \mathrm{~km}$ ESE from the starting point. This result could be possibly linked to Ionian Triassic Evaporites (Karakitsios, 1995, 2013; Tselentis et al., 2007) which are migrating upwards through the active local faults that form small grabens such as the one of Rion-Antirrion. Two more enclaves of similar P-velocity values are presented at superficial depths $(<4 \mathrm{~km})$ in profile 1A-1B (Fig.5c) between 50 and $70 \mathrm{~km}$ towards the SE. These 
features could also be related to ascending Triassic evaporitic bodies of Ionian unit penetrating the Tripolis alpine basement if there were sufficient borehole and geophysical data in order to confirm this observation. In the respective profile $2 \mathrm{~A}-2 \mathrm{~B}$ there is no evidence of penetrating salt bodies since the geologic background differs significantly. At a depth range between 12 and $17 \mathrm{~km}$, a lowvelocity zone is found that can be attributed to a ductile layer of the crust (Fig. 5d) as previous studies have revealed (Pham et al., 1996; Tiberi et al., 2000). This scenario would favour a deformation model which needs a crustal detachment horizon between the upper crust and upper mantle, located at the end of the low-angle normal fault (Lister and Davis, 1989).

\section{Conclusions}

In this study, a local 1-D velocity model was calculated through error minimization method in order to perform tomographic inversion using the obtained earthquake travel-times. Data recorded by HUSN and CRLN were used in order to carry out the procedure of LOCAL TOMOGRAPHIC SOFTWARE (LOTOS).

Based on the distribution of velocity anomalies, $\mathrm{Vp} / \mathrm{Vs}$ ratio values a clear correlation with the known tectonic features in the study area was seen, which could be an indirect argument for the reliability of the obtained models. At shallower depths $(5-15 \mathrm{~km})$, low velocities for both $\mathrm{P}$ and $\mathrm{S}$ waves with large $\mathrm{Vp} / \mathrm{Vs}$ ratio were mainly observed either close to the main segments of the AFZ or in proximity of the Quaternary basins (Patraikos Gulf). Similar values were found to be associated to main faults, implying fracturation and fluid penetration along the plane. High-velocity structures accompanied by low $\mathrm{Vp} / \mathrm{Vs}$ ratio were linked to unfractured parts of the crust such as the RionAntirrion and Nafpaktos basins.

Two cross-sections of absolute P-velocity were performed in order to obtain a more reliable geological model for the area of Patraikos and Western Corinth Gulf. An ascending body characterized by P-velocities ranging from 6.2 to $6.4 \mathrm{~km} / \mathrm{sec}$, in Patraikos Gulf, could be linked to Triassic salt diapirs while a low-velocity layer below $12 \mathrm{~km}$ in the area offshore of Aigion was attributed to a dactile zone which would favour a deformation model of a crustal detachment horizon between the upper crust and upper mantle.

The results obtained by LOTOS algorithm, in most cases, were in accordance with available geologic and tectonic data. The performance of a 4-D Local Earthquake Tomography becomes evident since there is need of a high-precision temporal velocity models in order to distinguish whether high values of $\mathrm{Vp} / \mathrm{Vs}$ ratio are influenced by water-saturated rocks either due to primary porosity (sedimentary basins) or fracturation and fluid penetration through flat cracks along a fault plane. 

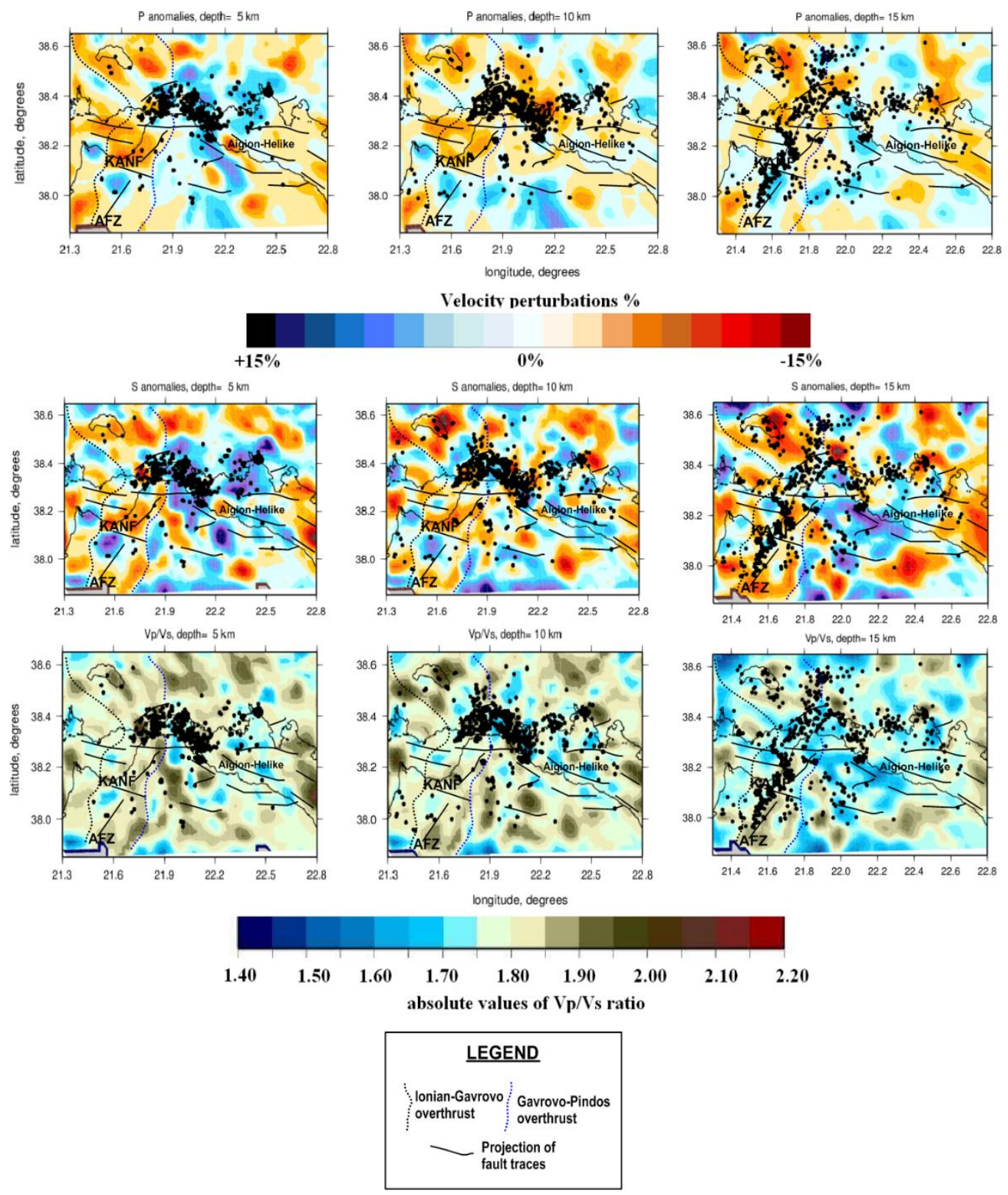

Figure 4 - Three dimensional distribution of P- (upper panel), S-velocity perturbations (central panel) and absolute $\mathrm{Vp} / \mathrm{Vs}$ ratio (lower panel) for the depth slices of 5,10 and $15 \mathrm{~km}$. 

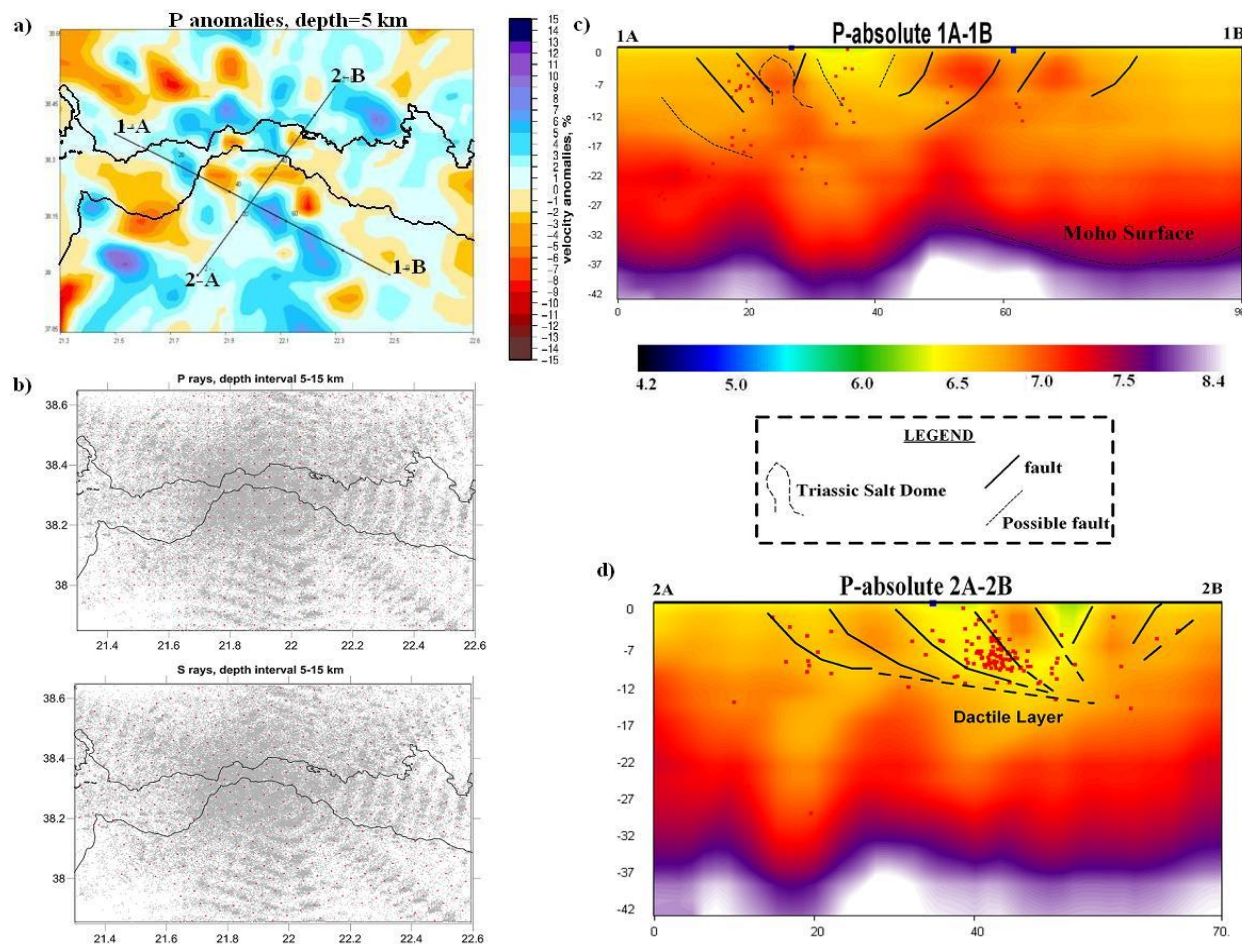

Figure 5 - a) Horizontal projection of the two profiles in NW-SE (1A-1B) and SW-NE (2A-2B) directions b) ray-path distribution of $P$ and $S$ waves c) Profile 1A-1B and d) Profile 2A-2B.

\section{References}

Armijo, R., Meyer, B., King, G.C.P., Rigo, A. and Papanastassiou, D., 1996. Quaternary evolutionof the corinth rift and its implications for the late cenozoic evolution of the Aegean, Geo hys. J. Int., 126, 11-53.

Chiarabba, C. and Frepoli, A., 1997. Minimum 1D velocity models in Central and Southern Italy: a contribution to better constrain hypocentral determinations, Ann. Geophys., 40(4), 937-954.

Cornet, F., Doan, M., Moretti, I. and Borm, G., 2004. Drilling through the active aigion fault: theaig 10 well observatory, Comptes Rendus Geoscience, 336, 395-406.

Drakatos, G., Melis, N., Papanastassiou, D., Karastathis, V., Papadopoulos, G. and Stavrakakis, G., 2002. 3-D Crustal Velocity Structure from Inversion of Local Earthquake Data in Attiki (Central Greece) Region, Natural Hazards, 27, N1-2, 1-14.

Gautier, S., Latorre, D., Deschamps, A., Sotiriou, A., Serpetsidaxi, A., Skarpelos, C., Virieux, J. and Tselentis, A., 2006. A New Passive Tomography of the Aigion Area (Gulf of Corinth, Greece) from the 2002 Data Set, Pure appl. geophys., 163, 431-453.

Humphreys, E. and Clayton, R.W., 1988. Adaptation of back projection tomography to seismic travel time problems, J. Geophys. Res., 93, 1073-1085.

Karakitsios, V., 1995. The influence of preexisting structure and halokinesis on organic matter preservation and thrust system evolution in the Ionian basin, northwestern Greece, $A A P G$ Bulletin, 79, 1567-1595.

Karakitsios, V., 2013. Western Greece and Ionian Sea petroleum systems, AAPG Bulletin, 79, 960-980.

Kaviris, I.G., 2003.Study of properties of the Eastern Corinth Gulf Seismic sources, PhD thesis, Athens 2003, pp.56-61, 74-84, 238-241.

Kissling, E., Ellsworth, W.L., Eberhart-Phillips, D. and Kradolfer, U., 1994. Initial reference models in local earthquake tomography, J. Geophys. Res., 99, 19635-19646. 
Klein, F.W., 1989. HYPOINVERSE, a program for VAX computers to solve for earthquake locations and magnitudes, U.S. Geological Survey Open-File Report, 89-314.

Koulakov, I., 2009. LOTOS code for local earthquake tomographic inversion. Benchmarks for testing tomographic algorithms, Bulletin of the Seismological Society of America, 99(1), 194-214.

Koulakov, I., Bindi, D., Parolai, S., Grosser, H. and Milkereit, C., 2010, Distribution of Seismic Velocities and Attenuation in the Crust Beneath the North Anatolian Fault (Turkey) from Local Earthquake Tomography, Bull. Seism. Soc. Am., 100(1), 207-224.

Lister, G. and Davis, G.A, 1989. The origin of metamorphic core complexes and detachment faults formed during Tertiary continental extension in the northern Colorado River region, U.S.A. Journal of Structural Geology, 11, 65-94.

Lyon-Caen, H., Papadimitriou, P., Deschamps, A., Bernard, P., Makropoulos, K., Pacchiani, F. and Patau, G., 2004. First results of the CRLN seismic network in the Western Corinth Rift: Evidence for old-fault reactivation, C. R. Geoscience, 336, 343-351.

Makropoulos, K.C. and Burton, P.W., 1981. A catalogue of Seismicity in Greece and the Adjacent Areas, Geophys. J. R. Astr. Soc., 65, 741-762, and Microfiche GJ65/1.

Nakajima, J., Hasegawa, A., Horiuchi, S., Yoshimoto, K., Yoshida, T. and Umino, N., 2006. Crustal heterogeneity around the Nagamachi-Rifu fault, northeastern Japan, as inferred from traveltime tomography, Earth Planets Space, 58, 843-853.

Papazachos, B. and Papazachou, C., 1997. The Earthquakes of Greece, P. Ziti and Co, Thessaloniki, Greece, 97-110.

Pham, V.N., Boyer, D., Chouliaras, G. and Bernard, P., 1996. Electrical conductivity and structure of the crust around the Gulf of Corinth (Greece) from magnetotelluric sounding (MTS) results, C. R. Acad. Sci. Paris, 323, 651-656.

Pitilakis, K., Makropoulos, K., Bernard, P., Lemeille, F., Berge-Thierry, C., Tika, Th., Manakou, M., Diagourtas, D., Raptakis, D., Kallioglou, P., Makra, K., Pitilakis, D. and Bonilla, L.F., 2004.The Corinth gulf soft soil array (CORSSA) to study site effects, C. R. Geosci., 336, 353-366.

Rietbrock, A., Tiberi, C., Scherbaum, F. and Lyon-Caen, H., 1996. Seismic slip on a low angle normal fault in the Gulf of Corinth: Evidence from high-resolution cluster analysis of microearthquakes, Geophys. Res. Lett., 23, 1817-1820.

Rigo, A., Lyon-Caen, H., Armijo, R., Deschamps, A., Hatzfeld, D., Makropoulos, K., Papadimitriou, P. and Kassaras, I., 1996. A microseismic study in the western part of the Gulf of Corinth (Greece): implications for large-scale normal faulting mechanisms, Geophys. J. Int., 126, 663-688.

Takei, Y., 2002. Effect of pore geometry on Vp/Vs: From equilibrium geometry to crack, $J$. Geophys. Res., 107(B2), 2043.

Tiberi, C., Lyon-Caen, H., Hatzfeld, D., Achauer, U., Karagianni, E., Kiratzi, A., Louvari, E., Panagiotopoulos, D., Kassaras, I., Kaviris, G., Makropoulos, K. and Papadimitriou, P., 2000. Crustal and upper mantle structure beneath the Corinth rift (Greece) from a teleseismic tomography study, J. Geophys. Res., 105(B12), 28159-28171.

Tselentis, G.-A., Serpetsidaki, A., Martakis, N., Sokos, E., Paraskevopoulos, P. and Kapotas, S., 2007: Local high resolution passive seismic tomography and Kohonen neural networks, application at the Rio-Antirrio Strait, Central Greece, Geophysics, 72(4), B93-B106.

Wessel, P. and Smith, W.H.F., 1995. New version of the Generic Mapping Tools released, EOS Trans. AGU, 76, 329. 